\title{
Influence of pregnancy on the onset of oestrus and luteal function after prostaglandin-induced luteolysis in cattle
}

\author{
L. A. Guilbault*, G. L. Roy*, F. Grasso* and P. Matton $\dagger$ \\ *Agriculture Canada Research Station, Lennoxville, Quebec, Canada JIM 1Z3; and \\ $\dagger$ Department of Biology, University of Sherbrooke, Sherbrooke, Quebec, Canada J1K $2 R I$
}

\begin{abstract}
Summary. Luteolysis was induced by an injection of $500 \mu \mathrm{g}$ cloprostenol (a prostaglandin (PG) analogue) in pregnant (P) Holstein heifers on Days 17 or 24 of gestation and in non-pregnant (NP) Holstein heifers on Day 17 of the oestrous cycle (oestrus = Day $0)$. Heifers in Groups P-17 $(\mathrm{N}=8)$ and P-24 $(\mathrm{N}=8)$ were inseminated twice whereas those in Group NP-17 $(\mathrm{N}=8)$ were not inseminated. Immediately after PG injection, embryos were recovered by uterine flushing $(400 \mathrm{ml})$ to confirm pregnancy in Groups P-17 and P-24. Uterine flushing with an equivalent volume of physiological saline was also done in Group NP-17. The interval from PG injection to oestrus and to the peak of luteinizing hormone ( $\mathrm{LH})$ as well as profile of increase in plasma oestradiol concentrations during that period did not differ $(P>0 \cdot 1)$ among the groups. However, the proportion of heifers exhibiting abnormal luteal phases (primarily of short duration) during the oestrous cycle after PG injection was greater $(P<0.01)$ in Group P-24 than in Groups NP-17 + P-17 pooled (6/8 vs 3/16). These results suggest that the previous presence of a conceptus did not have any effect on the onset of oestrus, or on plasma concentrations of oestradiol and LH after PG-induced luteolysis on Days 17 or 24 of gestation. However, luteal function during the subsequent oestrous cycle was impaired if heifers were 24 days pregnant when luteolysis was induced.
\end{abstract}

Keywords: pregnancy; luteolysis; conceptus; ovary; cattle

\section{Introduction}

The luteolytic effect of prostaglandin (PG) F-2 $\alpha$ or its analogues during the dioestrous period of the oestrous cycle and its use for synchronization of oestrus in cattle is well documented (Hafs et al., 1974; Britt et al., 1978; Cooper, 1981). Generally, the interval from time of PG injection to oestrus varies between 2 and 6 days and factors such as administration of GnRH agonist (MacMillan et al., 1985) or oestradiol benzoate (Dailey et al., 1986) or stage of dioestrus at which cows are injected (MacMillan \& Henderson, 1984) can alter the interval.

It has been suggested that size or maturity of the largest non-atretic ovarian follicle present at the time of injection of PGF-2 $\alpha$ or its analogues is related to the interval to oestrus (Scaramuzzi $e t$ al., 1980). Indeed, large follicles which are involved in control of onset of spontaneous luteolysis (Chupin \& Saumande, 1981; Villa-Godoy et al., 1985; Fogwell et al., 1985) are implicated in the return to oestrus in cows. Administration of follicular fluid before luteolysis inhibits follicular maturation, delays the rise in oestradiol-17 $\beta$ after PGF- $2 \alpha$ injection and consequently delays the onset of an ovulatory oestrus in sheep and cattle (Miller et al., 1979; Johnson \& Smith, 1985). During the oestrous cycle in cattle, more large antral follicles are observed in the ovary bearing the corpus luteum (CL) than in the contralateral ovary (Pierson \& Ginther, 1987a). In contrast, follicular growth in the CL-bearing ovary is decreased during early and mid-gestation (Rexroad \& Casida, 1975; Thatcher et al., 1986; Pierson \& Ginther, 1987b; Guilbault et al., 1988) due to an 
increased rate of atresia (Guilbault et al., 1986). This suggests that follicular function may be altered during pregnancy in cattle and that the response to a luteolytic dose of a PG analogue may be affected by functional changes of large antral follicles during early pregnancy in cattle. The objectives of this study were to determine the interval to the onset of oestrus, plasma concentrations of oestradiol and luteinizing hormone (LH) and luteal function after prostaglandininduced luteolysis during early pregnancy in cattle.

\section{Materials and Methods}

Experimental design. Holstein heifers which had displayed at least 2 oestrous cycles ( $21 \pm 2$ days) were used. On the day of oestrus (Day 0), 18 heifers were mated by natural service followed 8-16 h later by an artificial insemination (Group P). Eight additional heifers were not inseminated (Group NP). Luteolysis was then induced by an i.m. injection of a PG analogue (cloprostenol: $500 \mu \mathrm{g}$; Estrumate, Coopers Agropharm Inc. Willowdale, Ontario, Canada) administered to Group-P heifers on Day 17 (Group P-17; N = 10) or Day 24 (Group P-24; N = 8) of gestation and to Group NP heifers on Day 17 of the oestrous cycle. Immediately after PG injection, pregnancy in Groups P-17 and P-24 was confirmed by recovery of a conceptus with filamentous extraembryonic membranes after uterine flushing with $400 \mathrm{ml}$ sterile physiological saline ( 308 mosmol sodium chloride/l; pH 5.7). Uterine flushing with an equivalent volume of saline was also done in Group NP-17. Heifers that were mated but from which no conceptus was recovered in Group P-17 $(\mathrm{N}=2)$ were removed from the experiment. Heifers were observed for oestrous behaviour twice daily with a vasectomized bull, and only heifers that allowed mating were considered to be in oestrus.

Jugular blood samples were collected by venepuncture twice daily, starting 2 days before PG injection until 4 days after detection of oestrus and then every other day until the end of the next oestrous cycle. Plasma was harvested and stored at $-20^{\circ} \mathrm{C}$ until subsequent analyses. The CL-bearing ovary for the oestrous cycles before and after the injection of cloprostenol was identified by rectal palpation.

Hormone assays. Concentrations of progesterone were determined in all plasma samples collected. Concentrations of oestradiol and LH were measured in plasma samples collected from 2 days before PG injection until 4 days after detection of oestrus. Radioimmunoassays (RIA) for progesterone and oestradiol were adapted from procedures described previously by Bélanger $e t$ al. (1980) and utilized the same fully characterized antisera (progesterone: no. 147-A; oestradiol: no. 165-B). However, plasma (100 and $200 \mu \mathrm{l})$ was extracted with a mixture $(2 \mathrm{ml})$ of benzene: hexane $(1: 2 \mathrm{v} / \mathrm{v})$ for progesterone determinations (Louis et al., 1973) and plasma oestradiol was measured after extraction $(1.5-2.0 \mathrm{ml}$ plasma) with a mixture $(5 \mathrm{ml})$ of petroleum ether:ethyl acetate $(5 \cdot 5: 1 \mathrm{v} / \mathrm{v})$. Recovery of labelled steroids after extraction was $89 \pm 0.8 \%$ for progesterone and $88 \pm 1.2 \%$ for oestradiol. RIAs for progesterone and oestradiol were done without prior purification by chromatography. Tritiated steroids were used as tracers and separation of bound and free labelled steroids was by centrifugation after addition of dextran-coated charcoal.

Accuracy of steroid assays was determined by adding known amounts of progesterone (range: $0 \cdot 2-10 \mathrm{ng} / \mathrm{ml}$ ) or oestradiol (range: $10-120 \mathrm{pg} / \mathrm{ml}$ ) to plasma collected from an ovariectomized cow $(0.32 \pm 0.02 \mathrm{ng}$ progesterone $/ \mathrm{ml}$; $<1 \mathrm{pg}$ oestradiol $/ \mathrm{ml}$ ). Recovery of added $(x)$ versus measured $(y)$ steroid concentrations was described by linear regression for progesterone $\left(y=-17 \cdot 3+0.99 x ; \mathbf{R}^{2}=0.99\right.$; plasma volume extracted: $\left.25,50,100,200 \mu l\right)$ and oestradiol ( $y=9 \cdot 3+0.80 x ; \mathbf{R}^{2}=0.99$; plasma volume extracted: $0.5,1 \cdot 0,1 \cdot 5,2.0 \mathrm{ml}$ ). Progesterone or oestradiol concentrations did not differ $(P>0 \cdot 1)$ between assays and were not influenced $(P>0 \cdot 1)$ by assay volumes ranging from 25 to $200 \mu \mathrm{l}$ and 0.5 to $2.0 \mathrm{ml}$ plasma for progesterone and oestradiol respectively. Sensitivity of the assay, defined as the amount of steroid standard which yielded $95 \%$ of the d.p.m. in buffer control tubes, was $8 \mathrm{pg}$ progesterone/tube and $1 \mathrm{pg}$ oestradiol/tube. Serial dilutions of plasma samples collected from an ovariectomized cow and containing known amounts of progesterone or oestradiol of pooled plasma samples from cows in late pregnancy displayed inhibition curves that apparently were parallel (homogeneity of regression; $P>0.1$ ) to the standard curve of the respective steroid. Intra- and inter-assay coefficients of variation were $8.4 \%$ and $9.6 \%$ for progesterone and $14.5 \%$ and $16.7 \%$ for oestradiol assays respectively. Plasma LH concentrations were determined by the method described by Niswender et al. (1969): intra- and inter-assay coefficients of variation were $9.8 \%$ and $11.2 \%$ for LH and sensitivity of the assay was $0.4 \mathrm{ng} / \mathrm{ml}$.

Statistical analyses. Plasma hormone concentrations were analysed by analysis of variance in a split-plot design (Gill \& Hafs, 1971) utilizing the General Linear Model procedures of the Statistical Analysis System (SAS, 1979). Repeated measurements were taken over time and day was considered as a continuous independent variable. Each response was characterized by a day trend, which was analysed by polynomial regression. Tests of homogeneity of regression and orthogonal contrasts of the response curves (Guilbault et al., 1985) were used to detect differences in day trends among groups.

Least squares analysis of progesterone during the subsequent oestrous cycle was made relative to the day of first oestrus following the injection of cloprostenol. Luteal phases of the subsequent oestrous cycle were further classified as normal or abnormal based upon the magnitude and the duration of the rise in plasma progesterone concentrations and the length of the oestrous cycle during that period (Garverick \& Smith, 1986). Heifers with normal luteal phases during the subsequent oestrous cycle had an oestrous cycle of 18-24 days and progesterone concentrations were $>3.0 \mathrm{ng} / \mathrm{ml}$ before returning to $<1 \mathrm{ng} / \mathrm{ml}$ after Day 16. Heifers with abnormal luteal phases were grouped in two 
categories: (1) short duration, i.e. length of the oestrous cycle was $<18$ days and progesterone concentrations returned to $<1 \mathrm{ng} / \mathrm{ml}$ within 16 days and (2) normal duration but concentrations of progesterone never increased to $>2 \mathrm{ng} / \mathrm{ml}$ during that cycle. Differences in proportions of cows with normal and abnormal luteal phases were determined by $\chi^{2}$ analysis.

\section{Results}

Luteolysis occurred in all heifers after the injection of cloprostenol. Mean progesterone concentrations before injection were similar among groups $(P>0.1)$ and averaged $10.2 \pm 0.8 \mathrm{ng} / \mathrm{ml}$. Profiles of decrease in progesterone concentrations after the injection of cloprostenol were similar among groups $(P>0.1)$ and luteolysis (progesterone $<1 \mathrm{ng} / \mathrm{ml}$ ) was completed in all heifers between 24 and $40 \mathrm{~h}$ after injection (Fig. 1a). None of the heifers in Group NP-17 had started luteal regression before cloprostenol was given.
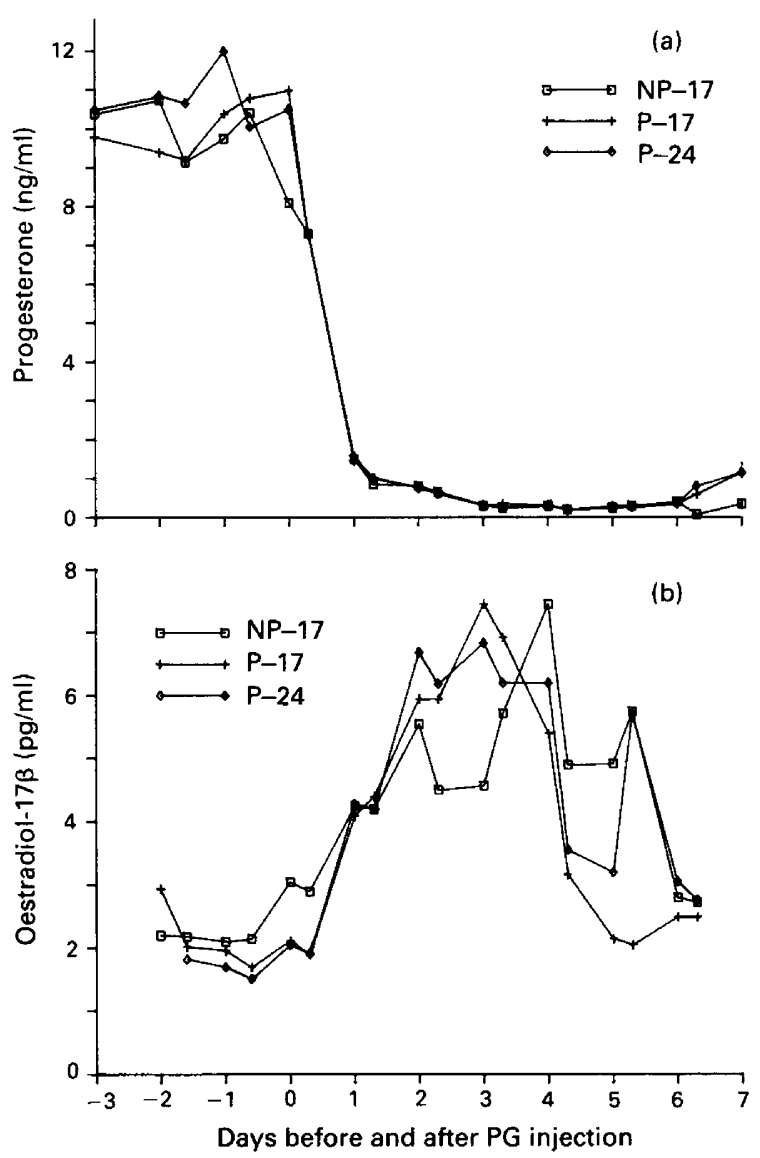

Fig. 1. Profiles of mean (a) progesterone and (b) oestradiol concentrations before and after PG-induced luteolysis in pregnant (P) and non-pregnant (NP) heifers on Days 17 or 24 of pregnancy or on Day 17 of the oestrous cycle (Day $0=$ day of PG injection; standard error at the mean of the independent variable $= \pm 0.1 \mathrm{ng}$ progesterone $/ \mathrm{ml}$ and $\pm 0.2 \mathrm{pg}$ oestradiol $/ \mathrm{ml}$; 8 heifers/group).

Mean intervals from time of injection of cloprostenol to oestrus and to peaks of oestradiol and LH were 84, 79 and $80 \mathrm{~h}$ respectively and did not differ $(P>0.1)$ among groups (Table 1). Interval from time of injection of cloprostenol to occurrence of the oestradiol and LH peaks varied 
considerably among heifers, ranging from 42 to $122 \mathrm{~h}$. Average peak plasma concentrations of oestradiol and $\mathrm{LH}$, which always occurred at or near oestrus, were $10.3 \mathrm{pg} / \mathrm{ml}$ and $4.9 \mathrm{ng} / \mathrm{ml}$, respectively, and did not differ $(P>0 \cdot 1)$ among groups. Likewise, profiles of increases in plasma oestradiol concentrations after cloprostenol did not differ $(P>0 \cdot 1)$ among groups (Fig. 1b). Profiles of plasma oestradiol concentrations increased from mean basal values of $2.2 \mathrm{pg} / \mathrm{ml}$ at the time of cloprostenol injection to mean peak values of $7 \cdot 5 \mathrm{pg} / \mathrm{ml} \mathrm{2-4}$ days later and returned to basal values thereafter.

Table 1. Time interval (mean \pm s.e.) and range from injection of cloprostenol to onset of oestrus and to peak concentrations of oestradiol and LH in pregnant (P) and non-pregnant (NP) heifers on Days 17 or 24 of pregnancy or on Day 17 of the oestrous cycle

\begin{tabular}{lccc}
\hline & $\begin{array}{c}\text { Group NP-17 } \\
(\mathrm{N}=8)\end{array}$ & $\begin{array}{c}\text { Group P-17 } \\
(\mathrm{N}=8)\end{array}$ & $\begin{array}{c}\text { Group P-24 } \\
(\mathrm{N}=8)\end{array}$ \\
\hline $\begin{array}{l}\text { Onset of oestrus } \\
\text { Interval (h) }\end{array}$ & $85 \pm 10$ & $83 \pm 4$ & $85 \pm 7$ \\
$\quad$ Range (h) & $42-122$ & $66-90$ & $50-122$ \\
$\begin{array}{l}\text { Peak of oestradiol } \\
\text { Interval (h) } \\
\text { Range (h) }\end{array}$ & $84 \pm 11$ & $77 \pm 7$ & $76 \pm 10$ \\
$\begin{array}{l}\text { Peak of LH* } \\
\text { Interval (h) }\end{array}$ & $42-122$ & $42-98$ & $42-122$ \\
$\quad$ Range (h) & $85 \pm 13$ & $75 \pm 6$ & $80 \pm 9$ \\
\hline *Five heifers (2 in Group NP-17, 1 in Group P-17 and 2 in Group P-24) not \\
showing a detectable rise ( $>1 \mathrm{ng} / \mathrm{ml}$ ) in LH were excluded.
\end{tabular}

Luteal function during the subsequent oestrous cycle in each group is illustrated in Fig. 2. The overall profiles of progesterone concentrations during the subsequent luteal phase differed among groups $(P<0.01)$. Such differences were due to a greater $(P<0.01)$ incidence of abnormal luteal phases during the subsequent oestrous cycle in Group P-24 than in pooled data from Groups NP-17 and P-17 (Fig. 2). Indeed, 6 out of 8 heifers in Group P-24 had an abnormal luteal phase during the subsequent oestrous cycle compared to 3 out of 16 heifers in the other two groups. Among the 6 heifers with an abnormal luteal phase in Group P-24, 5 had a luteal phase of short duration (12.8 $\pm 1 \cdot 0$ days); in the other, the luteal phase was normal in length but concentrations of progesterone were low. Abnormal luteal phases in the 3 heifers in Groups NP-17 and P-17 were of short duration (9.3 \pm 0.4 days). All short luteal phases were accompanied by an earlier return to oestrus.

After induction of luteolysis, ovulation occurred from ovaries ipsilateral to the ovary bearing the previous $C L$ in 11 heifers and 13 heifers ovulated from the contralateral ovaries. There was no relationship $(P>0 \cdot 1)$ between side of ovulation after induction of luteolysis and occurrence of short or 'dampened' luteal phases.

\section{Discussion}

Concentrations of progesterone before the injection of cloprostenol or during the mid-luteal phase of the subsequent oestrous cycle for heifers with a normal luteal phase were in the range of those reported by Hughes et al. (1987) for Holstein heifers. Maintenance of high plasma progesterone concentrations before the injection of the analogue indicates that all heifers had a functional corpus luteum at the beginning of the experiment. In contrast with Lukaszewska \& Hansel (1980) but in 


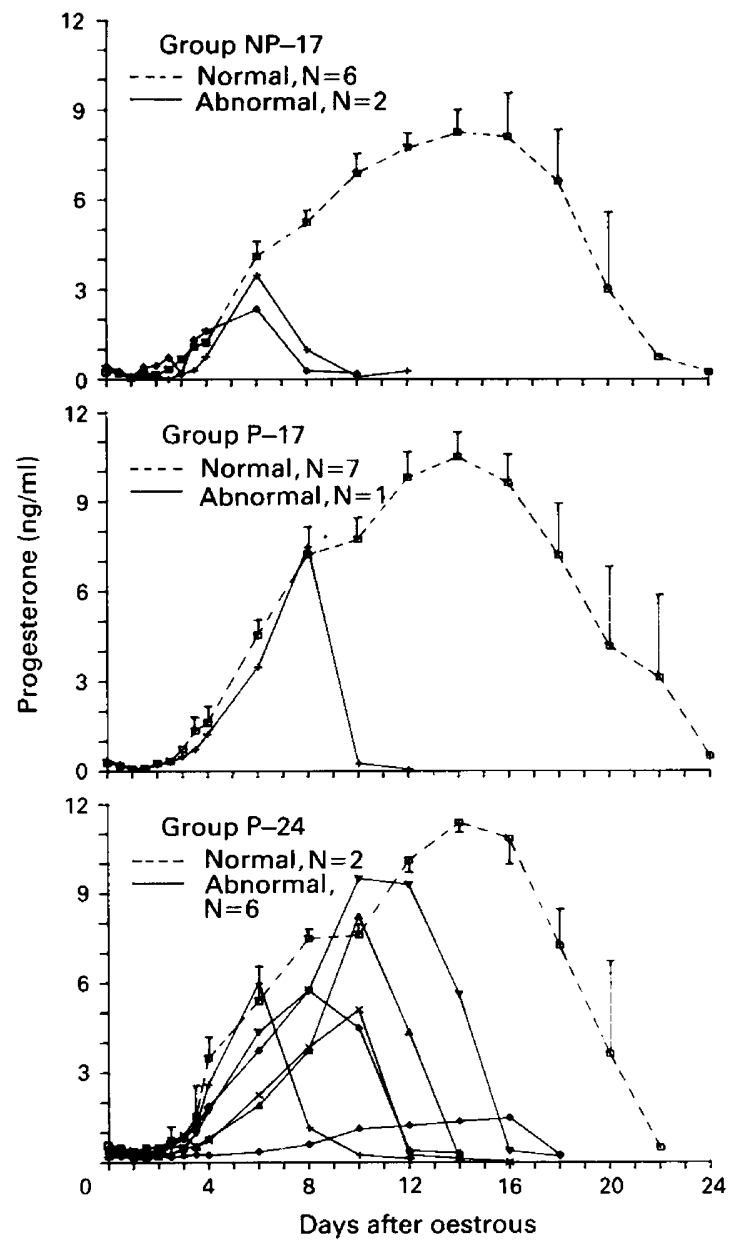

Fig. 2. Profiles of progesterone concentrations during the subsequent oestrous cycle after PG-induced luteolysis in pregnant (P) and non-pregnant (NP) heifers on Days 17 or 24 of pregnancy or on Day 17 of the oestrous cycle (Day $0=$ day of oestrus after PG injection, 8 heifers/group). Within each group, profiles of mean progesterone concentrations for heifers with a normal luteal phase and profile of progesterone concentrations for each heifer with an abnormal luteal phase are illustrated. Numbers of heifers with normal or abnormal luteal phases in each group are indicated.

agreement with Echternkamp \& Maurer (1983), plasma progesterone concentrations did not differ between pregnant and non-pregnant heifers early after mating or after oestrus. As determined by plasma progesterone concentrations, luteolysis was similar in pregnant and non-pregnant heifers and was complete in all animals within $24-40 \mathrm{~h}$ after injection of the PG analogue. This is well within the range reported by Chenault $e t$ al. (1976) and by Lindell et al. (1981) for cyclic and pregnant cows, indicating rapid luteal regression after administration of a luteolytic dose of PGF-2 $\alpha$. In the present experiment, responsiveness of the CL to the PG analogue was similar in pregnant and non-pregnant heifers. This suggests that follicular products involved in the luteolytic process after administration of PGF-2 $\alpha$ (Hughes $e t$ al., 1987) are unlikely to be affected early in pregnancy although follicular development is altered (Rexroad \& Casida, 1975; Thatcher et al., 1986; Pierson \& Ginther, 1987b; Guilbault et al., 1986, 1988). 
Ovarian follicles are implicated in the control of onset of oestrus (Scaramuzzi et al., 1980). This is further substantiated by the observation that injections of bovine follicular fluid during the follicular phase of the oestrous cycle in heifers and ewes (Miller et al., 1979), and before (Johnson \& Smith, 1985) or after (Quirk \& Fortune, 1986) a PG injection in cattle, delayed the normal preovulatory increase in plasma concentrations of oestradiol and lengthened the interval from luteolysis to oestrus by more than $100 \mathrm{~h}$. Using a schedule of detection of oestrus and of plasma sampling similar to that of Johnson \& Smith (1985), neither the interval to oestrus after PG-induced luteolysis nor the associated increase in plasma oestradiol and LH concentrations was influenced by pregnancy in the present experiment. It therefore appears that development of follicular components implicated in the onset of oestrus and possibly in ovulation (Ireland \& Roche, 1982) proceeds similarly in early pregnant and in non-pregnant animals after PG-induced luteolysis.

The main feature of the present experiment is that subsequent luteal function was impaired after PG-induced luteolysis in Group P-24 heifers as a result of a shortened luteal phase (5 cows) or reduced concentrations of plasma progesterone ( $1 \mathrm{cow})$ during the subsequent oestrous cycle. Shortened or dampened luteal phases frequently occur when cows first ovulate at puberty (Berardinelli et al., 1979) or during the early post-partum period (Garcia-Winder et al., 1987). Luteal function is also reduced in cows treated with PGF-2 $\alpha$ (Beal et al., 1980) or with indomethacin (Milvae \& Hansel, 1985) early in the oestrous cycle (Days 3-6). There are conflicting reports on the effect of uterine flushing on the concurrent luteal phases (Critser et al., 1980; Humblot \& Dalla Porta, 1984). In the present experiment, manipulations and flushing of the uterus were similar in the 3 groups and cannot account for the higher proportion of abnormal luteal phases in Group P-24 after the injection of cloprostenol.

Uterine factors may affect CL function. On one hand, the luteolytic effect of the uterus, most probably via its secretion of PGF-2 $\alpha$ is well recognized (Thatcher et al., 1986). On the other hand, it appears that a luteotrophin (possibly prostacyclin) of uterine (or ovarian) origin may be required for the development of complete functionality of the CL (Milvae \& Hansel, 1985; Rahmamian \& Murdoch, 1987). There is growing evidence that products of the conceptus may alter endometrial membrane dynamics which contribute to change in endometrial secretion of PGs at the time of maternal recognition of pregnancy (Thatcher et al., 1984; Gross et al., 1988). The presence of a conceptus for 24 days in the present experiment may have residual effects on the endometrium and luteotrophic factors required for normal luteal function may have been limited. Alternatively, short-lived elevations in concentrations of PGF-2 $\alpha$ metabolite (PGFM) associated with endometrial damage after abortion may have compromised luteal activity (Lindell et al., 1981). However, this seems unlikely since definite placental attachment is initiated only by Day 29 of gestation in the cow (King et al., 1980) and conceptuses were removed by Day 24 in the present experiment.

Since the CL has its origin within the follicle, follicular factors also appear to be implicated in the control of subsequent luteal function. Indeed, induction of ovulation by intra-follicular injection of gonadotrophins (Murdoch et al., 1983) or by an injection of luteinizing-hormonereleasing-hormone (LHRH) during the luteal phase (Rahmanian \& Murdoch, 1987) as well as administration of histamine within the preovulatory follicle (Halterman \& Murdoch, 1986) are associated with morphological disruption of the preovulatory follicle (Halterman \& Murdoch, 1986) and are followed by deficient luteal activity in the ewe. Moreover, the incidence of short luteal phases in early post-partum cows is reduced by pretreatment with a progestagen which appears to improve follicular maturation (Garcia-Winder et al., 1987). Follicular development is reduced in the ovary ipsilateral to the conceptus (Thatcher et al., 1986; Pierson \& Ginther 1987b; Guilbault et al., 1988) and there is histological evidence that the proportion of large atretic follicles is higher in pregnant than non-pregnant cows (Guilbault et al., 1986). Also, the function of large antral follicles appears to be altered by pregnancy since follicular fluid from large follicles of pregnant cows contains more inhibin than does that of non-pregnant cows (Bolt et al., 1986). Therefore, products originating from the Day-24 conceptus may have altered follicular function which, in a latent 
fashion, impinged on subsequent luteal function following PG-induced luteolysis during early pregnancy. Such effects of pregnancy contrast with those observed after administration of bovine follicular fluid which alters the follicular function implicated in the process of return to oestrus but is without any effect on subsequent luteal function in cows (Miller et al., 1979; Johnson \& Smith, 1985; Quirk \& Fortune, 1986). However, the present results also suggest that the change in follicular function implicated in short-lived luteal phases in early post-partum cows resuming ovarian activity may start to occur as early as Day 24 of pregnancy. This is likely since PG-induced abortion at 50-100 days of gestation also resulted in short oestrous cycles in heifers and frequency of short luteal phases increased as day of gestation at abortion increased (Copelin et al., 1987; Wright \& Kiracofe, 1988).

In summary, the present results indicate that, after PG-induced luteolysis, the process of return to oestrus and the associated increases in plasma $\mathrm{LH}$ and oestradiol were not affected by pregnancy. However, luteal function of the subsequent oestrous cycle was impaired if heifers were 24 days pregnant when luteolysis was induced.

We thank Mr A. Bélanger for the gift of antibodies against progesterone and oestradiol; Dr P. Brassard for embryo collection; N. Ouellet and J. R. Larivière for technical assistance; and L. Côté for typing this manuscript. Agriculture Canada Research Station, Lennoxville, Contribution No. 220.

\section{References}

Beal, W.E., Milvae, R.A. \& Hansel, W. (1980) Oestrous cycle length and plasma progesterone concentrations following administration of prostaglandin $F_{2 a}$ early in the bovine oestrous cycle. $J$. Reprod. Fert. 59, 393-396.

Bélanger, A., Caron, S. \& Picard, V. (1980) Simultaneous radioimmunoassay of progestins, androgens and estrogens in rat testis. J. Steroid Biochem. 13, 185-190.

Berardinelli, J.G., Dailey, R.A., Butcher, R.L. \& Inskeep, E.K. (1979) Source of progesterone prior to puberty in beef heifers. J. Anim. Sci. 49, 1276-1280.

Bolt, D.J., Chandlee, M.K. \& Kiracofe, G.H. (1986) Secretion of FSH by cultured pituitary cells is suppressed by bovine and porcine follicular fluids (FF). J. Anim. Sci. 63 (Suppl. 1), 349, Abstr.

Britt, J.H., Hafs, H.D. \& Stevenson, J.S. (1978) Estrus in relation to time of administration of prostaglandin $\mathrm{F}_{2 a}$ to heifers. J. Dairy Sci. 61, 513-515.

Chenault, J.R., Thatcher, W.W., Kalra, P.S., Abrams, R.M. \& Wilcox, C.J. (1976) Plasma progestins, estradiol and luteinizing hormone following prostaglandin $\mathbf{F}_{2 \mathrm{a}}$ injection. J. Dairy Sci. 59, 1342-1346.

Chupin, D. \& Saumande, J. (1981) Effect of exogenous prostaglandin and/or estrogen on luteolysis after electrocauterization of the largest follicles at the end of the bovine estrous cycle. Theriogenology 16, 497-504.

Cooper, M.J. (1981) Cloprostenol as a tool in the management of dairy cattle. Acta vet. scand. Suppl. 77, 171-180.

Copelin, J.P., Smith, M.F., Garverick, H.A. \& Youngquist, R.S. (1987) Effect of termination of pregnancy or long term progestogen treatment on subsequent estrous cycle length in heifers. J. Anim. Sci. 65 (Suppl. 1), 417, Abstr.
Critser, J.K., Rowe, R.F., Del Campo, M.R. \& Ginther, O.J. (1980) Embryo transfer in cattle: factors affecting superovulatory response, number of transferable embryos and length of post-treatment oestrous cycles. Theriogenology 13, 397-406.

Dailey, R.A., Price, J.L., Simmons, K.R., Meisterling, E.M., Quinn, P.A. \& Washburn, S.P. (1986) Synchronization of estrus in dairy cows with prostaglandin $\mathrm{F}_{2 a}$ and estradiol benzoate. J. Dairy Sci. 69, $1110-1114$.

Echternkamp, S.E. \& Maurer, R.R. (1983) Conception embryonic development and corpus luteum function in beef cattle open for two consecutive breeding seasons. Theriogenology 20, 627-637.

Fogwell, R.L., Cowley, J.L., Wortman, J.A., Ames, N.K. \& Ireland, J.J. (1985) Luteal function in cows following destruction of ovarian follicles at midcycle. Theriogenology 23, 389-398.

Garcia-Winder, M., Lewis, P.E., Townsend, E.C. \& Inskeep, E.K. (1987) Effects of norgestomet on follicular development in postpartum beef cows. J. Anim. Sci. 64, 1099 1109.

Garverick, H.A. \& Smith, M.F. (1986) Mechanisms associated with subnormal luteal function. J. Anim. Sci. 62 (Suppl. 2), 92-105.

Gill, J.L. \& Hafs, H.D. (1971) Analysis of repeated measurements of animals. J. Anim. Sci. 33, 331-336.

Gross, T.S., Thatcher, W.W., Hansen, P.F. \& Lacroix, M.C. (1988) Prostaglandin secretion by perifused bovine endometrium: secretion towards the myometrial and luminal sides at day 17 post-estrus as altered by pregnancy. Prostaglandins 35, 343-357.

Guilbault, L.A., Thatcher, W.W., Collier, R.J. \& Wilcox, C.J. (1985) Periparturient endocrine changes of conceptus and maternal units in Holstein heifers bearing genetically different conceptuses. J. Anim. Sci. 61, 1505-1515. 
Guilbault, L.A., Dufour, J.J., Thatcher, W.W., Drost, M. \& Haibel, G.K. (1986) Ovarian follicular development during early pregnancy in cattle. $J$. Reprod. Fert. 78, 127-135.

Guilbault, L.A., Grasso, F., Roy, G.L. \& Lapierre, S. (1988) Ovarian follicular development associated with embryonic mortality during early pregnancy in cattle. Theriogenology 29, 256, Abstr.

Hafs, H.D., Louis, T.M., Noden, P.A. \& Oxender, W.D. (1974) Control of the estrous cycle with prostaglandin $\mathrm{F}_{2 \alpha}$ in cattle and horses. J. Anim. Sci. 38 (Suppl. l), $10-21$.

Halterman, S.D. \& Murdoch, W.J. (1986) Ovarian function in ewes treated with antihistamines. Endocrinology 119, 2417-2421.

Hughes, T.L., Villa-Godoy, A., Kesner, J.S. \& Fogwell, R.L. (1987) Destruction of bovine ovarian follicles: effects on the pulsatile release of luteinizing hormone and prostaglandin $\mathrm{F}_{2 a}$-induced luteal regression. Biol. Reprod. 36, 523-529.

Humblot, P. \& Dalla Porta, M.A. (1984). Effect of conceptus removal and intrauterine administration of conceptus tissue on luteal function in the cow. Reprod. Nutr. Develop. 24, 529-541.

Ireland, J.J. \& Roche, J.F. (1982) Development of antral follicles in cattle after prostaglandin-induced luteolysis: changes in serum hormones, steroids in follicular fluid, and gonadotropin receptors. Endocrinology 111, 2077-2086.

Johnson, S.K. \& Smith, M.F. (1985) Effects of charcoalextracted bovine follicular fluid on gonadotropin concentrations, the onset of estrus and luteal function in heifers. J. Anim. Sci. 61, 203-209.

King, G.J., Atkinson, B.A. \& Robertson, H.A. (1980) Development of the bovine placentome from Days 20 to 29 of gestation. J. Reprod. Fert. 59, 95-100.

Lindell, J.-O., Kindahl, H. \& Edqvist, L.E. (1981) Prostaglandin induced early abortions in the bovine. Clinical outcome and endogenous release of prostaglandin $\mathrm{F}_{2 \mathrm{a}}$ and progesterone. Anim. Reprod. Sci. 3, 289-299.

Louis, T.M., Hafs, H.D. \& Sequin, B.E. (1973) Progesterone, $\mathbf{L H}$, estrus and ovulation after prostaglandin $\mathbf{F}_{2 \alpha}$ in heifers. Proc. Soc. exp. Biol. Med. 143, 152-155.

Lukaszewska, J. \& Hansel, W. (1980) Corpus luteum maintenance during early pregnancy in the cow. $J$. Reprod. Fert. 59, 485-493.

MacMillan, K.L. \& Henderson, H.V. (1984) Analyses of the variation in the interval from an injection of prostaglandin $F_{2 a}$ to oestrus as a method of studying patterns of follicle development during dioestrus in dairy cow. Anim. Reprod. Sci. 6, 245-254.

MacMillan, K.L., Day, A.M., Taufa, V.K., Peterson, A.J. \& Pearce, M.G. (1985) Effects of an agonist of gonadotrophin releasing hormone in cattle. II. Interactions with injected prostaglandin $\mathrm{F}_{2 \alpha}$ and unilateral ovariectomy. Anim. Reprod. Sci. 8, 213-223.

Miller, K.F., Critser, J.K., Rowe, R.F. \& Ginther, O.J. (1979) Ovarian effects of bovine follicular fluid treatment in sheep and cattle. Biol. Reprod. 21, 537-544.
Milvae, R.A. \& Hansel, W. (1985) Inhibition of bovine luteal function by indomethacin. J. Anim. Sci. 60, 528-531.

Murdoch, W.J., De Silva, M. \& Dunn, T.G. (1983) Luteal phase insufficiency in the ewe as a consequence of premature induction of ovulation by intrafollicular injection of gonadotropins. J. Anim. Sci. 57, 1507-1511.

Niswender, G.D., Reichert, L.E., Jr, Midgley, A.R., Jr \& Nalbandov, A.V. (1969) Radioimmunoassay for bovine and ovine luteinizing hormone. Endocrinology 84, 1166-1173.

Pierson, R.A. \& Ginther, O.J. (1987a) Follicular population during the estrous cycle in heifers. II. Influence of right and left sides and intraovarian effect of the corpus luteum. Anim. Reprod. Sci. 14, 177-186.

Pierson, R.A. \& Ginther, O.J. (1987b) Intraovarian effect of the corpus luteum on ovarian follicles during early pregnancy in heifers. Anim. Reprod. Sci. 15, 53-60.

Quirk, S.M. \& Fortune, J.E. (1986) Plasma concentrations of gonadotrophins, preovulatory follicular development and luteal function associated with bovine follicular fluid-induced delay of oestrus in heifers. J. Reprod. Fert. 76, 609-621.

Rahmanian, M.S. \& Murdoch, W.J. (1987) Function of ovine corpora lutea after administration of luteinizing-hormone-releasing hormone. J. Anim. Sci. 64, 648-655.

Rexroad, C.E., Jr \& Casida, L.E. (1975) Ovarian follicular development in cows, sows, and ewes in different stages of pregnancy as affected by number of corpora lutea in the same ovary. J. Anim. Sci. 41, 1090-1097.

SAS (1979) SAS User's Guide. Statistical Analysis System Institute, Inc., Cary, N.C.

Scaramuzzi, R.J., Turnbull, K.E. \& Nancarrow, C.D. (1980) Growth of Graafian follicles in cows following luteolysis induced by the prostaglandin $\mathrm{F}_{2 a}$ analog, cloprostenol. Aust. J. biol. Sci. 33, 63-69.

Thatcher, W.W., Bartol, F.F., Knikerbocker, J.J., Curl, J.S. \& Wolfenson, D. (1984) Maternal recognition of pregnancy in cattle. J. Dairy Sci. 67, 2797-2811.

Thatcher, W.W., Bazer, F.W., Sharp, D.C. \& Roberts, R.M. (1986) Interrelationships between uterus and conceptus to maintain corpus luteum function in early pregnancy: sheep, cattle, pigs and horses. $J$. Anim. Sci. 62 (Suppl. 2), 25-46.

Villa-Godoy, A., Ireland, J.J., Wortman, J.A., Ames, N.K., Hughes, T.L. \& Fogwell, R.L. (1985) Effect of ovarian follicles on luteal regression in heifers. $J$. Anim. Sci. 60, 519-527.

Wright, J.M. \& Kiracofe, G.H. (1988) Short estrous cycles and associated progesterone in serum of beef heifers aborted at various stages of gestation. Theriogenology 29, 497-504. 